Eos, Vol. 95, No. 51, 23 December 2014

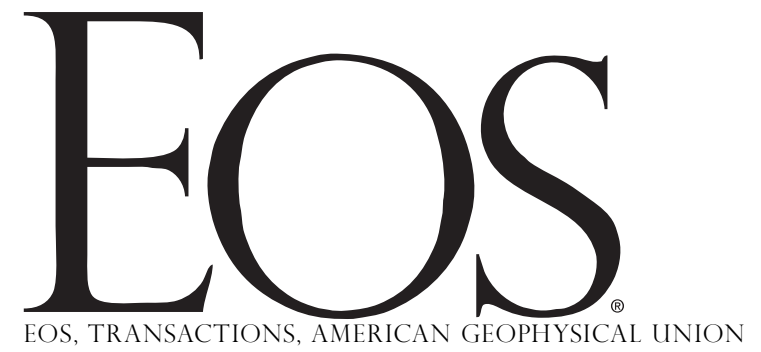

VOLUME 95 NUMBER 51

23 DECEMBER 2014

PAGES 485-492

\title{
Elders Recall an Earlier Tsunami on Indian Ocean Shores
}

\section{PAGES 485-486}

Ten years later, the Indian Ocean tsunami of 26 December 2004 still looms large in efforts to reduce tsunami risk. The disaster has spurred worldwide advances in tsunami detection and warning, risk assessment, and awareness [Satake, 2014].

Nearly a lifetime has passed since the northwestern Indian Ocean last produced a devastating tsunami. Documentation of this tsunami, which was in November 1945, was hindered by international instability in the wake of World War II and, in British India, by the approach of independence and partition.

The parent earthquake (magnitude 8.1) was centered west of Karachi along the Makran subduction zone (Figure 1). The tsunami registered on tide gauges, but intelligence reports and newspaper articles say little about inundation limits, and the consequences in terms of lives lost differ by an order of magnitude among the estimates in today's geophysical catalogs. What has been established about the 1945 tsunami falls short of what is needed today for ground-truthing inundation models, estimating risk to enlarged populations, and anchoring awareness campaigns in local facts.

Recent efforts to reduce tsunami risk around the Arabian Sea include a project in which eyewitnesses to the 1945 tsunami were found and interviewed (Figure 1) and related archives were gathered. Results are being made available through the Indian Ocean Tsunami Information Center (IOTIC) of the United Nations Educational, Scientific and Cultural Organization (UNESCO) in hopes of increasing scientific understanding and public awareness of the region's tsunami hazards.

\section{Makran Tsunami Hazards}

Tsunamis of nearby origin, which account for most tsunami fatalities worldwide [Yulianto

By D. M. KaKar, G. NAEEM, A. Usman, H. HaSAN, H. A. Lohdi, S. SRinivasalu, V. Andrade, C. P. RAJENDRAN, A. NADERI BEnI, M. A. HAMZEH, G. Hoffmann, N. Al Balushi, N. Gale, A. M. KODIJAT, H. M. FRITZ, AND B. F. ATWATER

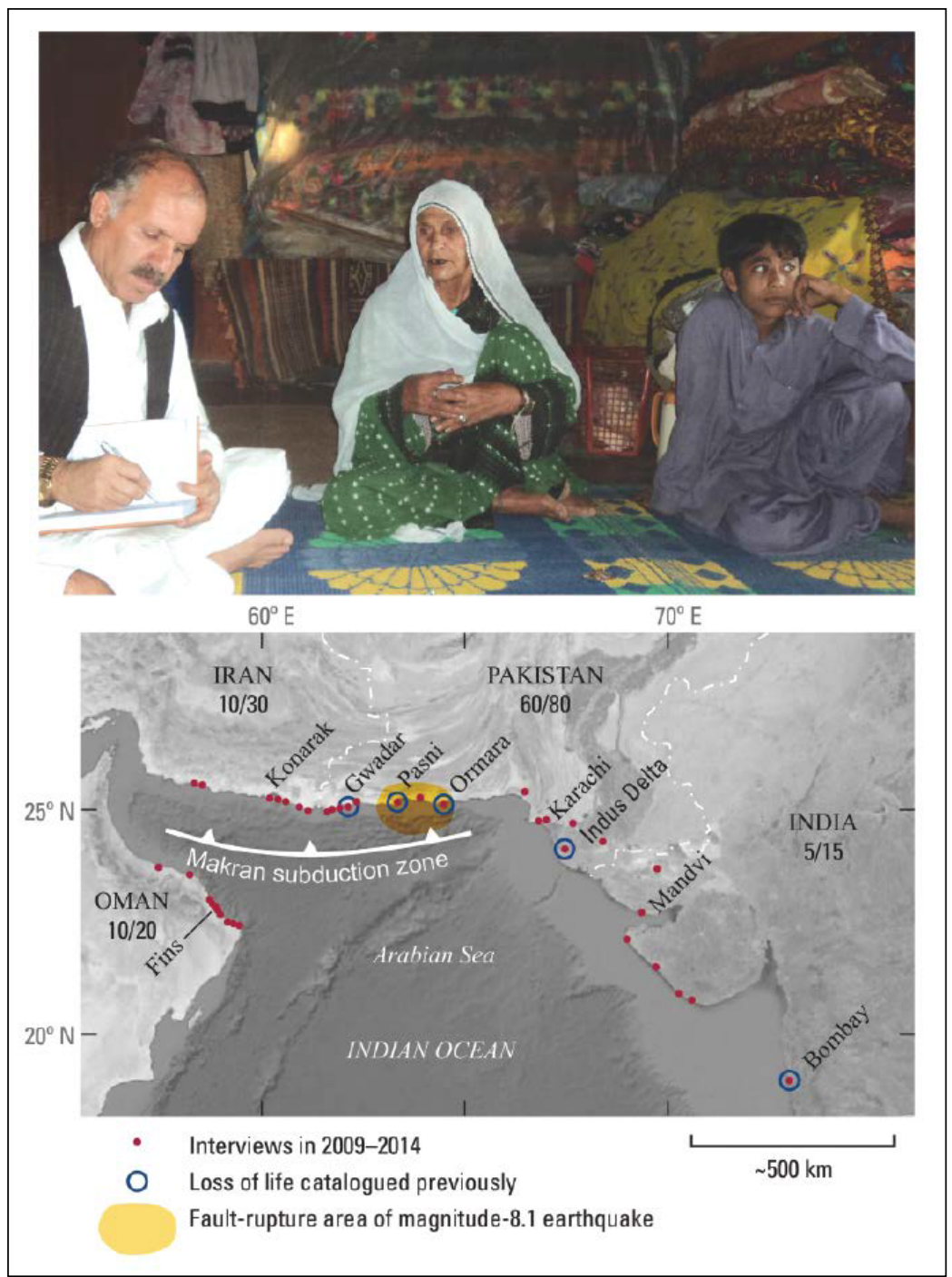

Fig. 1. (top) Rabia, age 74, recalls childhood memories of the 1945 Makran tsunami during an interview in Pasni, Pakistan, in 2013. Photo by Ghazala Naeem. (bottom) The tsunami originated along the Makran subduction zone, the seaward edge of which is marked by the white barbed line. An approximate source area of the parent earthquake (yellow) has been inferred from seismograms and coastal uplift [Byrne et al., 1992]. Tsunami fatalities, most of which occurred in what is now Pakistan, were previously documented at the sites marked by blue circles [Ambraseys and Melville, 1982]. Red dots locate recent interviews about the 1945 disaster. The fractions give round numbers of credible first-hand accounts (numerator) and total interviews (denominator) by country. 


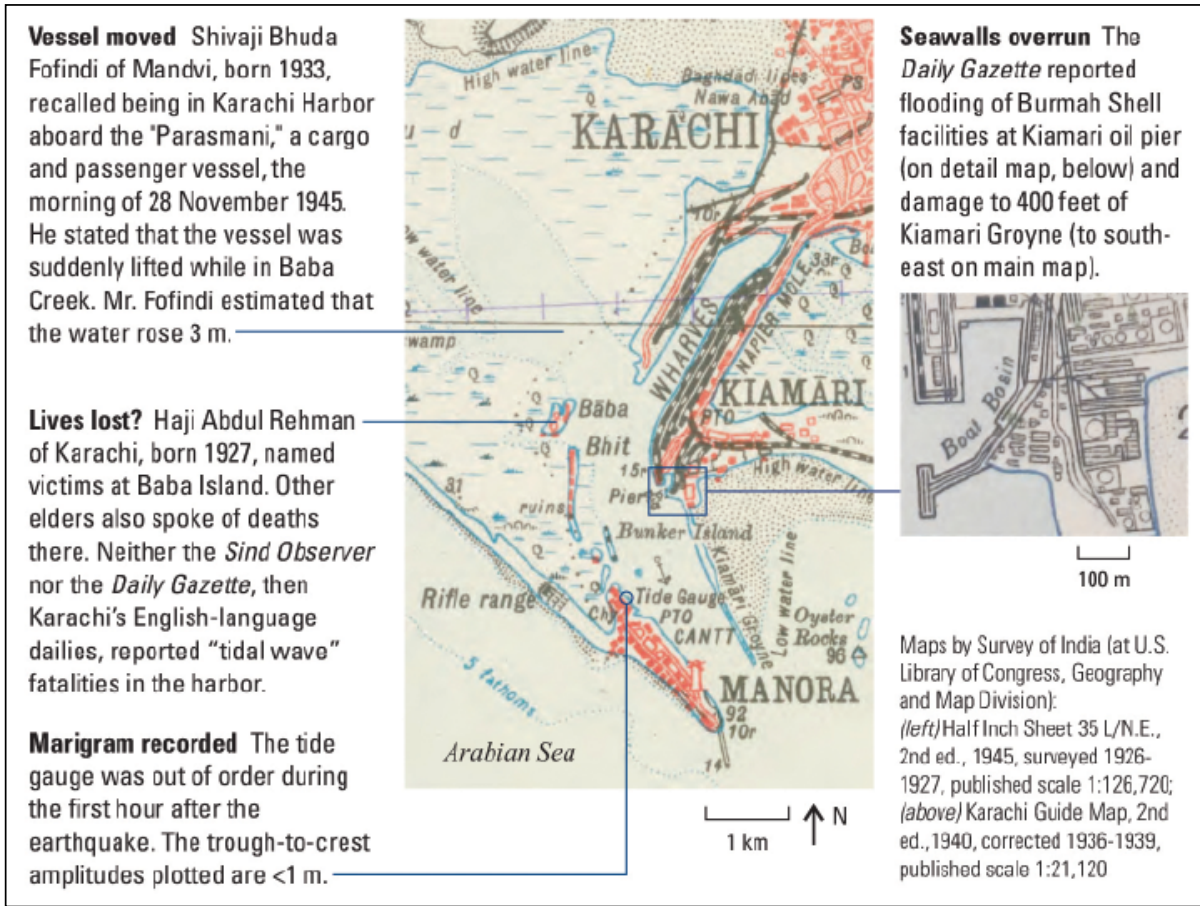

Fig. 2. Reported effects of the 1945 tsunami at the port of Karachi. The marigram mentioned is discussed by Neetu et al. [2011].

et al., 2010], pose hazards on the rim of the Arabian Sea [Okal and Synolakis, 2008]. The hazards originate along the Makran subduction zone, an active boundary between converging tectonic plates that descends northward beneath Iran and Pakistan. Were the zone to break along its entire 800-kilometer length, the resulting earthquake might attain magnitude 9 [Smith et al., 2013], and the ensuing tsunami might exceed 10 meters in height in parts of Oman, Iran, Pakistan, and India [Heidarzadeh et al., 2009].

This worst-case scenario scales up the 1945 Makran earthquake and tsunami. The magnitude 8.1 earthquake resulted from thrust rupture along an eastern part of the subduction zone [Byrne et al., 1992]. Submarine slides probably contributed to the ensuing tsunami, a mechanism also involved in the small 2013 tsunami in the Arabian Sea [Heidarzadeh and Satake, 2014]. The shaking and flooding in 1945 took place early on 28 November local time. Thirteen tsunami deaths were confirmed in Bombay (Mumbai). The rest of the known fatalities occurred in what is now Pakistan, along a coast then divided among two Baluchi states, an Omani enclave, and a British province. The fatality estimates range between about 300 [Ambraseys and Melville, 1982] and 4000 (http://www.ngdc.noaa.gov/hazard/ tsu_db.shtml).

\section{Spoken Histories of the 1945 Disaster}

Memories of the 1945 Makran tsunami have been gathered through recent interviews in Oman, Iran, Pakistan, and India. Some
60 eyewitnesses testified in Pakistan, and smaller numbers of people testified elsewhere (Figure 2). Most were children and a few were young adults in 1945. Written summaries of the accounts from Iran and Oman [Hamzeh et al., 2013; Hoffmann et al., 2013] are being augmented by videos and transcripts from Pakistan and India at a UNESCO website (http:// iotic.ioc-unesco.org/1945makrantsunami/).

Although some of the accounts sound like hearsay, others contain striking details. For example, the shaking in Ormara brought down a stone house that entrapped one eyewitness's recently married sister. The noisy approach of a wave in Pasni cut short the predawn Fajr prayer. The sea at Konarak entered a mosque and injured some who were praying there. No storm preceded flooding of a graveyard in Fins. Victims found near Karachi included a woman in Hindu bridal dress. Too many died in the Indus Delta for each one to receive a Muslim burial shroud. A boy aboard a ship moved by a sudden surge at Karachi learned of similarly unusual seas upon returning to his home port of Mandvi. Disaster relief from Baluchi tribes arrived by green jeep in Pasni and by black, white, and red horses in Ormara. Traumatic events can register as sharp memories [Berntsen and Thomsen, 2005; Sharot et al., 2007], and the 1945 disaster probably had that effect.

\section{Next Steps}

The eyewitness accounts offer chances to clarify tsunami hazards around the Arabian Sea. Inundation limits identified by eyewit- nesses can be used to improve simulations of tsunami sources and maps of tsunami hazards. A fuller picture of tsunami hazards in Karachi may emerge from comparing the spoken histories with newspaper archives (Figure 2). Whether the sea initially receded, as expected of a tsunami triggered mainly by submarine slides, might be tested through follow-up interviews.

The eyewitness accounts may find greatest use in tsunami awareness campaigns. Tsunami stories handed down from one generation to the next are said to have saved thousands of lives on an Indonesian island hit by the 2004 Indian Ocean tsunami [McAdoo et al., 2006]. A preparedness campaign in Pakistan in 2009 featured a local eyewitness who broadcast by radio his authoritative recollections of the 1945 disaster. It is hoped that such communitybased efforts will save lives during the next large tsunami on Arabian Sea shores.

\section{Acknowledgments}

UNESCO's Intergovernmental Oceanographic Commission (UNESCO-IOC) coordinated most of the field work under projects initiated by Jane Cunneen, Tony Elliott, and Edle Tenden. Funding came mainly from the United Nations Economic and Social Commission for Asia and the Pacific (UNESCAP). The Research Council of Oman supported the Oman work under grant ORG GUtech EBR 10 013. Additional support in Pakistan was provided by the United Nations Development Programme and by the Office of Foreign Disaster Assistance of the U.S. Agency for International Development (USAID-OFDA). Project workshops in Oman were hosted by the Directorate General of Meteorology and Air Navigation (DGMAN). Interviewers included D.M.K., G.N., A.U., and Attaullah Menghal in Pakistan; S.S., V.A., and Nilesh P. Bhatt in India; Emile Okal, H.M.F., M.A.H., Mohammad Afarin, and Hamzeh Ghaffari in Iran; and NA.B., G.H., D.M.K., G.N., and Emile Okal in Oman. This article was prepared by B.F.A. and improved by reviews from Nate Wood, Finn Løvolt, Peter Koltermann, and two anonymous referees.

\section{References}

Ambraseys, N. N., and C. P. Melville (1982), A History of Persian Earthquakes, 219 pp., Cambridge Univ. Press, Cambridge, U. K.

Berntsen, D., and D. Thomsen (2005), Personal memories for remote historical events: Accuracy and clarity of flashbulb memories related to World War II, J. Exp. Psychol. Gen., 134(2), 242-257, doi:10.1037/0096-3445.134.2.242.

Byrne, D. E., L. R. Sykes, and D. M. Davis (1992), Great thrust earthquakes and aseismic slip along the plate boundary of the Makran subduction zone, J. Geophys. Res., 97(B1), 449-478.

Hamzeh, M. A., E. A. Okal, J. Ghasemzadeh, and G. R. Beskeleh (2013), Study of the effects of the 1945 Pakistan tsunami on the Iranian Makran coast [in Farsi], paper presented at the First 
Eos, Vol. 95, No. 51, 23 December 2014

National Conference on Development of the Makran Coast, Chabahar Maritime Univ., Chabahar, Iran.

Heidarzadeh, M., and K. Satake (2014), Possible sources of the tsunami observed in the northwestern Indian Ocean following the 2013 September $24 M_{w} 7.7$ Pakistan inland earthquake, Geophys. J. Int., 199(2), 752-766, doi:10.1093/gji/ggu297. Heidarzadeh, M., M. D. Pirooz, and N. H. Zaker (2009), Modeling the near-field effects of the worst-case tsunami in the Makran subduction zone, Ocean Eng., 36(5), 368-376, doi:10.1016/ j.oceaneng.2009.01.004.

Hoffmann, G., M. Rupprechter, N. Al Balushi, C. Grützner, and K. Reicherter (2013), The impact of the 1945 Makran tsunami along the coastlines of the Arabian Sea (northern Indian Ocean)A review, Z. Geomorphol. Suppl., 57, suppl. 4, 257-277, doi:10.1127/0372-8854/2013/S-00134.

McAdoo, B. G., L. Dengler, G. Prasetya, and V. Titov (2006), Smong: How an oral history saved thousands on Indonesia's Simeulue Island during the December 2004 and March 2005 tsunamis, Earthquake Spectra, 22, S661-S669.

Neetu, S., I. Suresh, R. Shankar, B. Nagarajan, R. Sharma, S. S. C. Shenoi, A. S. Unnikrishnan, and D. Sundar (2011), Trapped waves of the 27 November 1945 Makran tsunami: Observations and numerical modeling, Nat. Hazards, 59(3), 1609-1618, doi:10.1007/s11069-011-9854-0.

Okal, E. A., and C. E. Synolakis (2008), Far-field tsunami hazard from mega-thrust earthquakes in the Indian Ocean, Geophys. J. Int., 172(3), 995-1015, doi:10.1111/j.1365-246X.2007.03674.x.

Satake, K. (2014), Advances in earthquake and tsunami sciences and disaster risk reduction since the 2004 Indian Ocean tsunami, Geosci. Lett., 1 , 15, doi:10.1186/s40562-014-0015-7.

Sharot, T., E. A. Martorella, M. R. Delgado, and E. A Phelps (2007), How personal experience modulates the neural circuitry of memories of September 11, Proc. Natl. Acad. Sci. U. S. A., 104(1), 389-394, doi:10.1073/pnas.0609230103.

Smith, G. L., L. C. McNeill, K. Wang, J. He, and T. J. Henstock (2013), Thermal structure and megathrust seismogenic potential of the Makran subduction zone, Geophys. Res. Lett., 40(8), 1528-1533, doi:10.1002/grl.50374

Yulianto, E., F. Kusmayanto, N. Supriyatna, and M. Dirhamsyah (2010), Where the first wave arrives in minutes: Indonesian lessons on surviving tsunamis near their sources, IOC Brochure 2010-4, 28 pp., U. N. Educ., Sci., and Cultural Organ., Paris. [Available at http://itic.ioc-unesco.org/index .php?option=com_content $\&$ view=article $\& i d=1678$ \&Itemid=1075\&lang=en.]

\section{Author Information}

-Din Mohammad KaKar, University of Balochistan, Quetta, Pakistan; email: dinkakar@ yahoo.co.uk; GHAZALA NAEEM, Islamabad; ABDULLAH Usman, Rural Community Development Council, Gwadar, Pakistan; HAIDER HASAN and HIRA ASHFAQ LOHDI, NED University of Engineering and Technology, Karachi, Pakistan; SeShaCHALAm SRINIVASALU, Anna University, Chennai, India; VANESSA ANDRADE, Indian Institute of Science, Bangalore, India; C. P. RAJENDRAN, Jawaharlal Nehru Centre for Advanced Scientific Studies, Bangalore, India; ABDOLMAJID NADERI BENI and MOHAMmAD AlI HAMZEH, Iranian National Institute for Oceanography and Atmospheric Science, Tehran, Iran; GOESTA HOFFMANN and NOORA AL BALUSHI, German University of Technology in Oman, Muscat; NORA GALE, United Nation's Educational, Scientific and Cultural Organization's Intergovernmental Oceanographic Commission, Indian Ocean Tsunami Warning and Mitigation System Secretariat, Perth, Australia; ARDITO M. KODIJAT, UNESCO-IOC IOTIC, Jakarta, Indonesia; HERMANN M. FRITZ, Georgia Institute of Technology, Atlanta; and BRIAN F. ATWATER, U.S. Geological Survey, Seattle, Wash.

(C) 2014 The Authors.

This is an open access article under the terms of the Creative Commons Attribution-NonCommercial-NoDerivs License, which permits use and

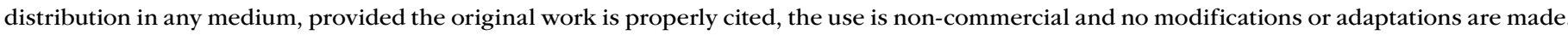

